\title{
近代の秋田 (久保田) 城址における公園化の背景と経緯 \\ Background and Circumstances of Modern Conversion of Akita (Kubota) Castle Site to a Park
}

\author{
野中 勝利*
}

\section{Katsutoshi NONAKA}

\begin{abstract}
The aim of this research is to elucidate the background and circumstances of the conversion of the Akita (Kubota) Castle site to a park in modern times. The national government determined the Akita (Kubota) castle site to be essential in 1873 . It was administered by the War Ministry, but the land was leased to local residents as farmland or pasturage. In 1890 the site was sold to the Satake family, descendants of the formal feudal lord, who entrusted its administration to the city of Akita. The city allocated income from leasing the grounds, moat, etc., for park improvement and maintenance. Akita Prefecture selected the castle site as a suitable location for rebuilding Shōkonsha, a Shinto shrine dedicated to the spirits of the war dead, that had been destroyed by fire. The prefecture planned to relocate Shōkonsha to the castle site and make it a prefectural park. The prefecture considered it problematic for the city of Akita to administer privately owned land, so the city canceled the administrative agreement in 1896. Afterwards, the prefecture purchased the central portion of the site from the Satake family, and the remainder was leased as a public park.
\end{abstract}

Keywords: Akita, Kubota, ruins of castle, park, modernization キーワード：秋田，久保田，城址，公園，近代化

\section{1. 研究の背景と目的}

近世城郭は明治維新によりその存立条件を喪失した。1869 年、 版籍奉還により旧藩主は藩知事になり、城址は兵部省の所管にな った。1872 年 2 月、兵部省が廃止され、陸軍省と海軍省が設置 されると、城址は陸軍省に移管された。1873 年 1 月、陸軍省は 全国の鎮台配置を改定し、その多くが旧来の城郭が充てられた。 この鎮台等の再編に伴い、「諸国存城並廃城調査」として全国の城 郭の存廃が一覧表で示された。

それによって「廃城」になった城址は払い下げの対象となった。 この払い下げの経過では今治城址で詳細に検討されている ${ }^{1)}$ 。ま た「廃城」後の公園化では、最初に城址を公園にした米沢と高知 を対象にした研究 ${ }^{2)}$ 、松山を対象にした研究 ${ }^{3}$ などがある。

一方、「存城」は陸軍省の所管になったが、すべての「存城」に 兵舎が置か犼てはいなかった。1889 年、軍備拡張に伴い練兵場や 射的場等の「増地買収」費の調達のため、全国の「存置习要セサ ル」旧城郭等を売却することになった ${ }^{4)}$ 。その対象となった 19 城 址のうち、1890 年に白河を除く 18 城址が旧藩主家あるいは自治 体に払い下げられた。この払い下げでは、旧藩主家に払い下げら れた若松城址 ${ }^{5}$ や高松城址 ${ }^{6}$ などでその経過が分析されている。

払い下げ以降、昭和戦前期までの城址の土地利用をみると、自 治体が城址の借用あるいは買収、管理の受託等によって、城址を 公園として整備や維持管理していたことが明確なのは、このうち 秋田、盛岡など 7 事例である。現在では旧本丸を中心に多くが城 址公園になっているが、払い下げ 18 城址のうち、昭和戦前期ま でに公園になったのは半数に満たなかった。

現在の城址公園は、城址が土地利用としての公園に転換されて から、近代化の過程でその整備が積み重ねられて形成されている。 歴史的共有財である城址の空間履歴をその社会背景とともに捉え ることは、今後の城址整備において不可欠である。特に公園化が 進められた発端の経緯は、その後の公園整備を規定する要因にも なったことから、その解明に意義を認めることができる。

城址の「公園化」についての研究はまだ個別事例が積み上げら れている段階である。1 1890 年に払い下げられた城址の公園化 7 事例でみると、管見の限り、鳥取城址を対象に、旧藩主池田家一 の払い下げ以降、公園に至る経過が分析されているのみである7”。

そこで本稿ではこの 7 事例の中で最も早く公園化が進んだ秋田 (久保田）城址 ${ }^{8}$ を対象として、公園化に至る背景や経緯を明ら かにすることを目的とする。秋田では城址が旧藩主佐竹家に払い 下げられると、佐竹家はその管理を秋田市に委嘱し、その後秋田 県が公園として整備するという、他の城址にはみられない経過を 辿っている。本稿では、こうした経緯を明らかにするため、研究 対象期間を 1890 年の払い下げの前後から、秋田県が公園化のた め城址の買収と借用をした 1896 年までとする。なお秋田県によ る公園整備における長岡安平の設計思想に関寸る研究はあるが、 公園化の経緯については言及されていない9 。

研究にあたっては、秋田市文書法制課が管理している秋田市の 当時の行政資料と議会資料、秋田県公文書館が管理している秋田 県の当時の行政資料と議会資料を基礎資料とした。なおいずれも 当時の資料をすべて保存しているわけでないが、保管されている 資料を可能な限り確認した。なお秋田県に関しては参事会の会議 録を確認することはできなかった。そのほか陸軍省関係の資料は アジア歴史センターで確認した。また秋田県官吏から郡長などを 歴任し、秋田市長になった御代弦の日誌翻刻も参照した ${ }^{10}$ 。

\section{2. 城址の払い下げまでの城址を取り巻く動き}

\section{(1)「存城」後の城址の土地利用}

「存城」になった秋田城址は、陸軍省の通達により「秋田城郭 番人」の二人が雇われていた ${ }^{11)}$ 。政府は城址内の士族邸宅地を買 い上げ、相当の移転料を支払い、建物の払い下げを進めた。また 1878 年には城址に残っていた八幡神社と秋田神社が氏子らによ って移転され、その費用が政府に請求されている ${ }^{12)}$ 。

1880 年 7 月には城址で火事があり、当時まだ残っていた旧本

筑波大学芸術系 
丸の建物のほとんどが焼失した ${ }^{13)}$ 。その後も、城址内の立ち枯れ 木や風倒木などの 127 本の樹木を入札により払い下げたり ${ }^{14)}$ 、城 址の古い建物、二階建ての櫓や土蔵、門などを入札で払い下げた りしている ${ }^{15)}$ 。

しかし陸軍省は城址を積極的に利用することはなかった。1878 年 11 月に陸軍省が布達した「土地家屋人民工貸渡規則」 ${ }^{16)}$ に基づ き、濠を鯉の飼養のため貸与したり ${ }^{17)}$ 、土地を薬草の栽培や牧畜 として貸与したり、土手敷の雑草は植物の肥料や牛馬の飼料に充 てることも許可している ${ }^{18)}$ 。住民らの出願により農業などの用途 として暫定的に利用されていた。

1884 年から 4 年間、秋田に宣教師として滞在した米国人は城 址を、「すっかり荒れ果て、その建物は見る影もなく荒廃していた が、自然の美しさを保っていた」と評しているが ${ }^{19)}$ 、樹木などの 緑地の管理は少しずつ進められていた。繁殖していた狐や狸を捕 獲していたり ${ }^{20)}$ 、「城番人」に「雑柴」の刈り取りを指示したり している ${ }^{21)}$ 。指示書では、尺回り以上の雑木の伐採を禁じている ほか、細木であっても、「松、杉、桑、茶、ケヤキ、クルミ、柿、 栗、桃、コウゾ、桜、イチョウ」の刚り取りを禁じている。

\section{（2）城址利用における秋田県と秋田市の意向}

このような城址は「荊棘曼延シ恰モ山谷ノ姿」であり、省みる と「人民ノ愁惜」があった。「城番人」二人では、適切な管理は行 き届いていなかったようである。それを背景として、1888 年 4 月、秋田県は陸軍省（第二師団）に、「秋田城址」での「公園」の 設置を願い出ることを次のように検討していた ${ }^{222}$ 。

秋田県にはほかに公園はあるが、市街から遠くにあり有名無実 である ${ }^{23)}$ 。一方、城址は市街を眼下に眺め、西に海洋、東に山岳 の景色があり、「四時ノ風光観楽」の公園を開設したい。ただし陸 軍省所管のため、「公園」に組み替えられないのであれば、無料の 借地による「遊園」の開設でも良い。地形は変更せず、在来の立 木はそのまま保存する。なお資料にはこのような推敲されている 文案が綴られており、実際に提出されたかは不明である。

いずれにしても、秋田県は城址を主体的に利用する意向を有し ていたことは確かである。なお 1890 年 2 月、秋田県は「秋田城 址」を遊園にするための借用の件は、城址が払い下げられる見込 みになり見合わせることにした ${ }^{24)}$

陸軍省が「存城」の一部を払い下げる準備を進めていたことは、 「風評」として各地に伝わっていた。1889 年 8 月 7 日付で秋田 市長(小泉吉太郎) は旧藩主佐竹家の当主である義生宛てに「秋田 旧城地之儀二付懇願」を提出した。その内容は次の通りである ${ }^{25)}$ 。

「旧縁故」をもって願い出る者に払い下げられるという「風評」 が一時的に勃興し、旧士民の中には出願する考えもある。しかし 秋田市会（以下、市会とする）では「全市共有物トナシ永ク甘棠 追慕ノ情念」があり、基本財産として市民の幸福をはかるため、 城地の特別払い下げの出願を議決し、その準備をしていた。しか し佐竹家が出願するということで、市会ではありがたく思ってい る。一方、「他県人」等に渡れば不幸であり遺憾である。もし佐竹 家の所有地になったら「格別ノ御由緒」をもってそのまま本市に 預けていただくか、別段の方法で扯借させていただきたい。

後述するようにその後実際に佐竹家では払い下げの出願をして いる。なお文中では、「公園」等の具体的な利用方法については言 及されていないが、秋田市にも主体的な利用の意向があった。

\section{（3）旧藩主佐竹家への払い下げ}

陸軍省本省から各師団に対し、払い下げ対象の旧城郭地は「元 城主」による出願に対しては公売にしないで評価額で払い下げる 趣旨を、各地方庁を経由して旧城主へ告知するよう通達があった。 第二師団から秋田県を通じて知らされた佐竹義生は陸軍大臣に
宛てて、1889 年 8 月 16 日付で「秋田舊城趾及附属地御拂下願」 を提出した。「秋田舊城地」は、「祖先佐竹義宣以来ノ居城ニシテ 歳ヨ経ルコト殆ント三百餘年 王政維新ニ至ルマテ歴代祖先辛苦 経営」し、今日に至るが、「繢綣之情二於テ忘ルルコト能ハサル」 として、払い下げられたら「有形之儘保存仕度精神」であると述 べている。「保存」とあるが、払い受け後の土地利用については言 及していない。

1889 年 11 月に第二師団から陸軍大臣に宛てて、「秋田盛岡若 松白河各舊城郭地元該城主へ拂下之儀二付伺」が提出された。秋 田旧城主の佐竹家、盛岡旧城主の南部家、若松旧城主の松平家、 白河旧城主の阿部家から、祖先歴代伝来と縁故をもつて各城郭の 旧形の維持の情意を表して払い下げの出願があり、各々の払い下 げの出願書や評価額の調書を添えて提出した。

この第二師団からの伺いに対し 1890 年 2 月、「秋田城」は 4,500 円で払い下げることが決まった ${ }^{26)}$ 。佐竹家に払い下げられた土地 は、「旧城地」に加え、「旧練兵場地」「旧火薬庫敷地」も含まれ ていた ${ }^{27)}$ 。

\section{3. 秋田市への管理の委嘱}

\section{(1) 管理の条件と計画}

城址の払い下げを受けた佐竹家は、その管理を秋田市に委嘱す ることにした。その理由は、先述したように 1889 年 8 月に秋田 市が佐竹家に城址扯借の出願があったことを挙げている ${ }^{28)}$ 。

1890 月 4 月 26 日の秋田市参事会 (以下、市参事会とする) で、 「旧城地受託管理ノ件」が議案にあがった。契約書案には、「旧主 家」の所有に帰した秋田旧城地の当市への管理委嘱に対して、確 実に管理するための条件が記されている。その条件には、(1)従来 の風致を損なわない限りにおいて多少地形の変更をしても良い、 (2)道路や架橋を設け、畑や宅地等の区画を定めて収入を図っても 良い、(3)在来の木石を売買、交換して宅地経営の資金に充当して も良い、(4) 30 年以内の年限で貸地、貸家で収入を得ることは随意 とする、(5)管理年限は 10 年を一期とし、一期ごとに契約を更新 する、6)管理費用を差し引き純利益がある場合は 7 割を旧主家、 3 割を市の収入にする、(7)植え継ぎの方法を設けて、雑木のほか 林立する用材を適宜伐採して良い、8神社および学校の敷地等に 充当する場合は特に旧主家の認可を得ることなど、8 項目が挙げ られている ${ }^{29)}$ 。その後の参事会の審議では項目の修正や追加など が検討されたが、比較的秋田市に有利な条件だった。

佐竹家との交涉過程は不明であるが、最終的には 1890 年 6 月 17 日付で佐竹義生から秋田市に管理が委嘱された。その条件は以 下の通りである ${ }^{30)}$ 。

一、従来の地形を変更し木石を売買する時は伺いをたてること

一、将来の事業の計画方法等を取り調べの上、申し出ること

一、管理中に取り計らいの不都合があると認められた際はいつ でも返納すること

かなり簡潔に、大きな枠組みだけの管理条件を設定し、その後 に詳細な事業計画を策定することにしている。なお条件設定の中 では具体的に「公園」としての利用には言及されていない。

同じ 6 月 17 日付で「睢城地管理」に関して、佐竹家家扶から も市長宛てに文書が提出された。そこでは、旧来の風致を損なわ ないようにみだりに樹木を伐採しないこと、佐竹家では財政上困 難にもかかわらず、祖先が経営していたことから多額の金をもつ て陸軍省から払い受けたので、佐竹家にも利益になるような計画 にしていただきたいとの内意が伝えられた ${ }^{31}$ 。所有者である佐竹 家の経済的利益への配慮が望まれたいた。この佐竹家からの管理 委嘱については 6 月 22 日の市参事会で報告された ${ }^{32) 。}$

そして 7 月 16 日の市会で、「秋田旧城地管理方法取調委員組 織」の議案が提出された。将来の事業を計画し、その方法や順序 
などを定め、公園、池沼、田畑、宅地、通路などの区画などを検 討する組織だった。市参事会員から 2 名、市会議員から 3 名、市 公民から 2 名の 7 名の委員で構成するものだった ${ }^{33)}$

こうして佐竹家からの管理委嘱の条件だった事業計画が検討さ れた。1891年 3 月 17 日付で秋田市から佐竹義生に「舊城地取調 調書」が提出され、3 月 23 日付で佐竹義生が了承した。その過程 では佐竹家側との下交渉があったとみられる。

この「萑城地取調調書」の第一条には「旧城地二對スル計画」 として、(1)不用木石売却、(2)公園開設、(3)道路修繕及ひ築造、(4) 樹木植立、(5)学校建築地選定、(6)御別荘地選定、(7)八幡社及びそ の他の社地選定、8不用の土地及び涼貸し渡し、9)収支予算の 9 項目が挙げられている。第二条から順に、各項目を条として説明 がされている。その内容は表一 1 の通りである。

これをみると既存の風致を活かしつつ、荒廃している不要な木 石を取り除き、多くの植樹によって風致を向上寸る計画になって いる。旧本丸を公園地に設定し、土地の整地、庭園の改修と増設、 周囲の植樹をする一方、将来は神社の立地を見込んでいる。逆に みれば神社の立地を想定した旧本丸の風致増進といえる。遊歩者 のために道路や休㕷所の整備も予定している。また佐竹家の別荘

表- 1 「旧城地取調調書」における「旧城地に対する計画」

\begin{tabular}{|c|c|c|}
\hline 条 & 項目 & 内 \\
\hline 第二条 & 不用木石売却 & 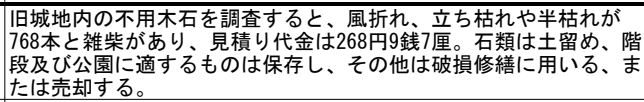 \\
\hline 第三条 & 公園開設 & 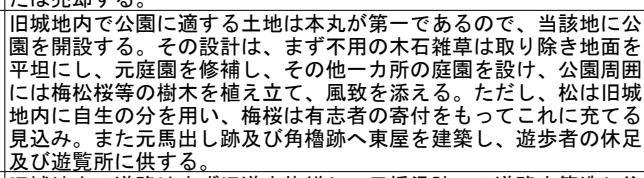 \\
\hline 第四条 & 築路㫦 & 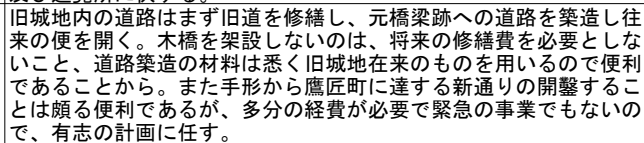 \\
\hline 第五第 & 樹木の植え立 & 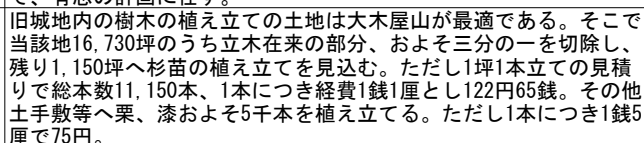 \\
\hline & & 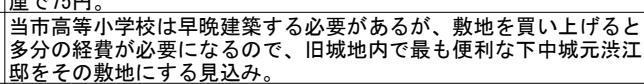 \\
\hline 第七 & :御別荘地選 & 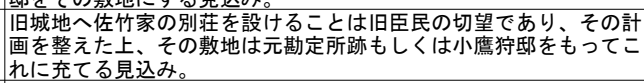 \\
\hline 第 & \begin{tabular}{|l|} 
八幡社及びそ \\
の他社地選定
\end{tabular} & 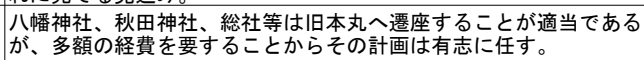 \\
\hline & 不用のさ & 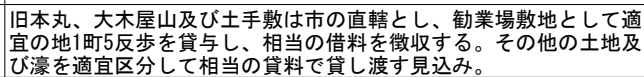 \\
\hline & & \\
\hline
\end{tabular}

建設を期待するとともに、自らの学校敷地の確保を見込んでいる。 取り除く木石の売却費や土地や濠の賃料を整備費に充当するほか、 一部の事業は有志の行為を期待するなど、事業化予算が並行して 検討されていた。94収支予算は、これらの内容を予算化したもの であり、表一 2 の 1891 年度予算として記載した。継続事業では なく 1891 年度の単年での事業化を計画していた。予算は独立会 計としているが、80 円の市費を充てている。

この「調書」ではじめて明確に城址の旧本丸を「公園」として 位置づけているが、予算項目では「公園」は使用されていない。 なお後の新聞報道で、佐竹義生が「嚄秋田城趾公園」と命名した とあるが ${ }^{44)}$ 、秋田市の行政資料や議会資料では確認できない。

\section{（2）予算と審議からみた秋田市の管理}

『秋田市会事務簿』『秋田市会議事録』及び『旧城地管理事務簿』 から確認できた「旧城地」に関する 1891 年度以降の予算と決算 を一覧したものが表一 2 である。

初年度の決算をみると、不用木石の売却収入のほか、寄付金も 当初の見込みには及ばなかったが、比較的多く集めている。しか し収支では 3 百円の借入金があった。二年め以降は貸地料収入を 中心とした収支予算が計上されている。

初年度の「樹木植付費」は予算に対し約 1 割強の執行にすぎな かった。これは杉苗木を 11,150 本、漆、栗等を 5 千本植樹する 計画だったが、実際には杉苗木 50 本、漆苗木 500 本、栗 5 千本 だったためである。途中の参事会では、単価が見込みより高いと して本数を減らしたり、他の樹種への変更を決めたりなど、柔軟 な対応をしていた。1 894 年度は杉苗木 7 千本と漆 1 千本、 1895 年度は杉苗木 9,939 本、漆 1 千本が予算化されるなど、年間に千 本単位での植樹が予定された。

陸軍省による秋田城址の払い下げにあたって、見積額を算出す るための調査では、旧城地の立木は 3,858 本 (杉 2,583 本、松 486 本、雑木 789 本) だった ${ }^{35)}$ 。枯れ木や風倒木が毎年売却されて公 園管理の収入にされていたが、新たな植樹によって、本数でみれ ば緑地的には徐々に充実していたとみられる。ただし参事会や市 会では、樹種の選定や植樹の配置などの造園的な議論はみられな いが、杉、漆、栗の植樹は産業振興の意図があったことが考えら れる。なお 1892 年 4 月に市内の有力者たちが公園経営について 協議し、常緑樹の中に花樹が必要だとして桜 1,170 本を寄付した。 その後、5 本、10 本と篤志家から桜が寄付されたらしい ${ }^{36)}$ 。ただ し当時の秋田市の行政資料や市参事会資料からそれを裏付ける記 載は確認できなかった。

予算の費目には「公園費」はなく、1891-92 年度は「庭園費」 があり、1893 年度以降は「遊園費」になった。1895 年 11 月の

表- 2 旧城地歳入歳出予算・決算

\begin{tabular}{|c|c|c|c|c|c|c|c|c|c|}
\hline (単位：円) & 1891年度予算 & 1891年度決算 & 1892年度予算 & 1892年度追加 & 1892年度決算 & 1893年度予算 & 1894年度予算 & 1895年度予算 & 備考 \\
\hline 収入 & 1353 & 1151 & 175 & 77 & 207 & 218 & 237 & 212 & \\
\hline 木石等売払金 & 318 & 455 & & & & & & & \\
\hline 貸地料 (濠含む) & 194 & 170 & 157 & & 142 & 153 & 151 & 121 & 土地と濠の賃貸料 \\
\hline 雑収入 & & 17 & 13 & 52 & 10 & 9 & 9 & 9 & 枯損木、不用石等の売却 \\
\hline 寄付金 & 655 & 209 & 5 & & 29 & 2 & 2 & 2 & \\
\hline 前年度繰越金 & $80 * 1$ & & & 26 & 26 & 55 & 76 & 83 & 余剰金、未収金 \\
\hline 借入金 & $106 * 2$ & 300 & & & & & & & 水道資本からの借入 \\
\hline 支出 & 1353 & 1125 & 175 & 77 & 154 & 218 & 237 & 212 & \\
\hline 管理費*3 & & 117 & 24 & & 24 & 49 & 48 & 46 & 監守人給料等 \\
\hline 樹木植付費 & 258 & 34 & 85 & 32 & 56 & 115 & 129 & 100 & 杉、漆、栗等の植え付け \\
\hline 土木費 & 995 & 695 & & 20 & 17 & 13 & 15 & 25 & 道路、土手修縜費等 \\
\hline 遊園費*4 & 50 & 279 & 38 & 40 & 52 & 29 & 29 & 32 & 掃除、腰掛け等 \\
\hline 雑費 & & & & & 5 & & & & \\
\hline 予備費 & 50 & & 13 & & & 12 & 16 & 9 & \\
\hline 借入金利子 & & & 15 & $\triangle 15$ & & & & & \\
\hline 差引残金 & & 26 & & & 52 & & & & \\
\hline
\end{tabular}

注）小数点以下四捨五入、そのため合計の端数が合わないことがある。空欄は該当する費目がないことを示す。

$* 1 ： 1891$ 年度は市費、 $* 2:$ 経費の減額もしくは樹木売却金の増額、 $* 3: 1892$ 年度は監守人給料、*4: 1892 年度予算までは庭園費 
市会で、議員から市が管理している城址は「公園」ではなく、た だ家人が楽しむ「遊園」にすぎないと指摘されたことに対し、市 当局者は確かに「遊園」であると答弁している。「公園」にするた めにはどれ位の資金を費やすかの標準はなく、ただ衆人の楽しむ 所くらいであると回答している。事業計画では「公園開設」と女 るが、いまだ公園の体をなしていないとも吐露している ${ }^{37)}$ 。そう したことが予算の費目名に反映されていた。なお予算書をみると 常駐する監守人を置いて管理していた。

\section{4. 城址の公園化の経緯}

\section{（1）招魂社の移転と城址の「公園化」}

秋田では市街地郊外に戈辰の役で戦没した兵士を祀る招魂場が 1869 年に創建され、1875 年に政府の通達に伴い招魂社に改称し た。招魂祭はこの招魂社で執り行われていた。この招魂社は 1893 年 12 月に焼失した。これは「看守人の失火」だったらしい ${ }^{38) 。}$ 日清戦争が終結し、その戦没者を加えると招魂社の再建は焦眉の 問題だった。またそれに伴い広い招魂祭場の確保も求められた。

当時山本郡長だった御代弦は、1895 年 9 月 16 日、招魂社再建 の件で県庁から招集があった。御代の日誌によると、翌 17 日、 県会議事堂で市郡の発起人 50 名くらいが会合し、招魂社の再建 について協議した。しかし議論が沸騰し、決まらなかった。18日 も引き続き協議し、結局、旧城内本丸に招魂社を再建し、あわせ て秋田神社も遷し、かつ旧城内を県公園にすることを決定した ${ }^{39)}$ 。 日誌には他の参加者名は記されていないが、平山靖彦秋田県知事 をはじめ、御代が後に佐竹家との交涉を共にした秋田市長の羽生 氏熟や河辺郡長の川井忠雄もいたとみられる。県と市郡の長がこ の一体的な整備計画で合意した。

\section{（2）秋田市会での議論}

県知事を含む有志者での合意を受け、1895 年 9 月 26 日付で秋 田県内務部長は秋田市長に次のような文書を出した。寺内村の招 魂社を城址内に移転するとともに「一大縣公園」を創設する。管 内に偉人や功労者を崇祀する堂宇を建設し、国民忠愛の義気を作 興すると同時に義人傑士の芳名を後世に表す目的で城址を譲り受 ける方針である。そのことに対する意見の照会だった ${ }^{40)}$

翌 27 日、市長はこの照会に対する回答案を市会に諮るため市 会議長に提出した ${ }^{41}$ 。そその内容は、本市は佐竹家からの委嘱で城 址を管理しており、同家がさしつかえなければ本市には問題はな く、その事業を切望することを市会の決議をもって、市長から秋 田県内務部長に回答するという内容だった ${ }^{42)}$ 。

すぐには市会が開かれず、10月 18 日付で市会議員 17 名から 議長宛に「目下ノ一問題タル旧城地习縣公園トナシ招魂社习移転 轉セシムルノ儀ハ本市ノ利害二至大ノ関係ヨ有スルハ論ヨ待タス 故二市會決議ノ必要」があるとして、市会開設請求書が提出され た ${ }^{43)}$ 。

それに応じて 10 月 21 日に市会が開かれた。市会では佐竹家か ら市への管理委嘱の目的は公園の設置や樹木の栽培など旧城を永 遠に維持する精神にほかならないという意見や、もともと城郭内 にあった秋田神社を戻し、勤王志士の霊魂を祀る招魂社を縁故の ある城址に再建寸ることの意義から県公園を設けることは旧藩主 も受容するはずとの発言があり、県からの照会を承諾する意見が 出された。一方、城址は市の所有地ではなく、県公園は県の事業 であり、市会で議論するのは権限外であるという意見や、市は城 址を管理しているだけで、旧藩主に意見をする立場にはないとの 発言もあった。

議論百出し、継続審議になった。10月 23 日の市会でも建議す るかしないかで議論は収束せず、10月 26 日に三たび市会が開か れた。審議の過程で、採決の見込みとなり、反対者は退席したた
め、結局、満場一致で可決された ${ }^{44)}$ 。旧城へ県公園を設置して招 魂社を移転することは、佐竹家及び当市の利益と認められること から、それに要する地所を秋田県へ譲渡することを認めるという 意見を佐竹家へ申し述べることになった ${ }^{45)}$ 。

次いで 11 月 1 日の市会で、佐竹家に提出する上申書が審議さ れた。この上申書案の概要は次の通りである。秋田城地の管理に ついは、本市の資金も使い、不足分は毎年の収入をもって漸次 着手している。公園の開設もその設備はまだ途中である。八幡神 社、秋田神社等を旧本丸に遷座する計画は有志者に任せることに なっていたが、その目的を実行する時機がなく遺憾であった。本 城は「歴史上名跡トシテ永遠二保存スル」必要があるのみならず 「旧藩臣民ノ永ク旧恩习忘レサルノ情義」において、「一市」の力 をもって維持するよりは、「一県」の力で保存する方が確実、堅固 である。経費は多いが収益の少ない旧本丸、旧二の丸は県費での 保存に委ね、収益が多く経費が少ない旧三の丸以外は本市が管理 することは、佐竹家の利益であり、本市の利益でもある。以上の ことから、公園の開設、神社の移転等の了承を、市会の決議をも って上申する。

この上申案に対し、先の建議で反対した議員を含む二人が、文 言を微に入り細に入り㛜しい指摘をして廃充を訴えたが、採決の 結果、原案通り可決された ${ }^{46)}$ 。

\section{(3) 佐竹家との交渉}

秋田市会で招魂社の移転と県立の公園化等が同意された翌日 (10月 27 日)、御代山本郡長は県知事に面会し、羽生市長と三者 で招魂社の件について協議している。既に川井河辺郡長は招魂社 の交渉のため上京していた。平山知事は広島藩出身で、この三名 は秋田藩出身である。御代は戊辰の役で藩主とともに戊辰の役に 出陣しているなど、佐竹氏とは面識がある。佐竹家との交涉はこ の三人、特に御代が中心となって進められた。

10 月 29 日にはこの三人で東京の佐竹邸に出向いて大縄家令に 面会し、招魂社の建築敷地として城址の譲り受けについて最初の 交渉を行った。佐竹家側は城址の譲渡を渋っていたらしく、その 後も、 11 月 1 日、 3 日、 5 日、 6 日と連日のように大縄家令と協 議を重ねている。11月 7 日夜には酒席で御代と大縄は衝突し、翌 8 日には大縄から御代に前来の談判はすべて不調であると通牒が あったが、9 日には一転して合意された。そして 10 日に御代は平 山知事、羽生市長とともに佐竹邸に出向き、佐竹義生に面会して

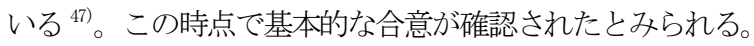

そして 12 月 8 日に県会議事堂で、県会議員や御代らの有志者 が集まり招魂社について協議会が開かれた。羽生市長から佐竹家 との交渉の顛末について報告があった。翌 9 日も引き続き協議会 が開かれ、県庁側の提案通りで合意された ${ }^{48}$ 。

御代弦の日誌からこのような一連の経過がわかるが、佐竹家と の交渉内容は伺い知ることはできない。一方、県側は一貫して「公 園化」ではなく、「招魂社」の協議を前面に出していることがわか る。招魂社や秋田神社の移転と県立の公園化は一体とした計画と されているが、発端は招魂社の移転であったことの証左といえる。

\section{（4）秋田県会での建議と公園化の予算可決}

1895 年 12 月 11 日の県会に「縣公園地二関スル建議」が提出 された。議員 30 名のうち 29 名からの建議だった。これは先の 12 月 9 日の協議会で合意された県庁側の提案の内容だったとみ られる。県当局からの諮問ではなく、県会での審議をより円滑に する方策がとられた。

その中で、城址の状況を「今ヤ漸ク荒無廢頽二属セントスルハ 其等ノ嘆惜二堪へサルへ」と嘆いている。ただし「土地八高壮二 シテ風色ノ佳絶ナルコト闔國其比 見サル」と評価し、公園にす 
れば「天下ノ美観」になると主張している。さらに焼失した招魂 社を移転し、「義士ノ誉」と「公園ノ美」とを後世に伝えることは 「千載ノ快事」だと指摘している。そして「縣民敵愾忠愛ノ元氣 ヨ振作スル」として議案を提出した。その費用は、「公園敷地譲受 代」として 6 千円、「公園借地料」として 7 千円、「公園造営費」 として 5 千円、合計 1 万 8 千円としている。そのまま修正もなく 可決された ${ }^{49)}$ 。城址は、秋田市による管理が 5 年間されていたに もかかわず寂しい状況だった。基本的には土地や濠の貸し渡し料 収入による整備だったため、自ずと限界があった。

この建議書では招魂社よりも「公園化」を前面に出している。 予算化を伴うことから「公園」を建議する必要があった。なお建 議書では、戊辰の役での 695 名の戦没者を祀る招魂社が 1893 年 に焼失したが、移転に伴い、1894-1895 年の日清戦争の「殉国 奉公八忠士」も祭祠するとしている ${ }^{50)}$ 。このように祭祀する人数 の増加が、招魂祭を開くための広い敷地を求めた。

そして 12 月 19 日、秋田県会に公園費予算案が提出された。既 に11月から始まった県会で1896年度予算案が番議されていたが、 12 月 11 日の建議の可決に伴う予算の追加だった。

建議による公園費総額に変更はないが、1896 年度からの三力年 継続事業にした「秋田縣公園費継続年期及支出方法」として、1896 年度は土地の買収費 6 千円のみで、 1897 年度と 1898 年度で整備 する計画である（表- 3)。説明書の中で、旧本丸の一部を買い受 け、その他は借り受けて公園を造営するとしている。また当該年 度で支出額に残金が生じるか、残事業がある時は、次年度の支出 額に加えて、本事業を完成させるとしている。1898年度までに公 園の造営をする計画だった ${ }^{51}$ 。

この予算案は翌 12 月 20 日に審議され、質疑もなく満場一致で 可決された ${ }^{52)}$

\section{（5）秋田市の抵抗と受容}

城址の公園化に伴う佐竹家との合意や、公園化に伴う予算化が 決まった秋田県から、1896 年 2 月 8 日付で秋田市に対し、「侯爵 佐竹家ノ委嘱习受ケ秋田嚄城地习管理セルハ市制上為ス可ラサ 儿儀二付自今其管理习解ク可シ」という訓令があった ${ }^{53)}$ 。まだ秋 田市は正式に委嘱された管理を解除していなかった。なお羽生市 長は前年 11 月に辞意を表し、1月 29 日の秋田市会で、御代弦が 市長候補者の選挙で当選していた。羽生は上京し、秋田を不在に していた。御代は 2 月 29 日に裁可となり正式に市長に就任した。

羽生市長が辞表を提出したのは、秋田市と佐竹家との間で城址 の貸借問題が膠着し、佐竹家の大縄家令を市長に据えてその打開 を画策したからだという ${ }^{54)}$ 。羽生は城址の秋田県への譲渡に関し て、県知事らの佐竹家との交涉の場に同席している。しかし羽生

表- 3 公園費継続年期及支出方法 ${ }^{55}$

\begin{tabular}{|c|c|c|c|c|c|}
\hline 年度別 & (円) & 項目 & (円) & 内訳 & （円） \\
\hline 1896年度支出額 & 6,000 & 公園造営費 & 6,000 & 公園土地買収費 & 6,000 \\
\hline \multirow[t]{9}{*}{ 1897年度支出額 } & 6,000 & 公園造営費 & 6,000 & 樹木培養費 & 400 \\
\hline & & & & 石材費 & 200 \\
\hline & & & & 石段石垣費 & 338 \\
\hline & & & & 営繕費 & 302 \\
\hline & & & & 雑給 & 1,181 \\
\hline & & & & 備品費 & 35 \\
\hline & & & & 消耗品費 & 10 \\
\hline & & & & 雑費 & 34 \\
\hline & & & & 公園附属地借地料 & 3,500 \\
\hline \multirow[t]{8}{*}{ 1898年度支出額 } & 6,000 & 公園造営費 & 6,000 & 樹木培養費 & $\overline{400}$ \\
\hline & & & & 路面築造費 & 360 \\
\hline & & & & 営繥費 & 734 \\
\hline & & & & 雑給 & 918 \\
\hline & & & & 備品費 & 15 \\
\hline & & & & 消耗品費 & 50 \\
\hline & & & & 雑費 & 23 \\
\hline & & & & 公園附属地借地料 & $\underline{500}$ \\
\hline 公園費 & 8,000 & & & & \\
\hline
\end{tabular}

注）小数点以下四捨五入
の思いは秋田市への貸与だったことになる。先述のように前年 11 月 1 日の市会で県への譲渡を認める上申書を決議した時期は、佐 竹家との交渉で上京中だった。

2 月 8 日の市参事会で秋田県からの訓令にどのように対処する かが議論された。羽生市長が不在のため市長代理の根田助役が議 長になった。議長のほか 4 名が出席した。このうち 2 名は訓令に 沿って城址を返上寸ることに同意する意見だった。残りの 2 名は 委嘱による管理が問題であるならば、佐竹家から借用すべきと主 張した。意見は二分したが、議長の助役は借用する意見に賛同し て、それが決議になった。このことを在京の羽生市長に伝えて佐 竹家の意思を確認することになった ${ }^{56)}$ 。この決定は羽生の意向と 同じだった。

結局、2月 17 日の市会で、秋田県からの訓令に対しては以下の ような対応が満場一致で決まった。本市が城址を管理することは、 市の公益のために委嘱を願い出て許された経緯がある。県庁が「管 理」といら名称が市制上差し支えると指摘しているので、本市で は「拝借地」と改称し、さらに勧業を進める。ただし「県公園」 等の設置のために佐竹家が県知事と契約した時にはその部分をい つでも返上する ${ }^{57)}$ 。なお秋田市は事前に秋田県側と交涉していた。 秋田市の立場を配慮し、秋田県と佐竹家との契約が済むまで猶予 する内容だった。

しかし 3 月 25 日付で大縄家令から市長宛に、過般、旧城地に つて秋田県知事から管理を解除するべきとの訓令があったよう に、速やかに返納の手続きをするよう、また拝借地とする改称の 願いは許容できないという文書が届いた ${ }^{58)}$ 。佐竹家としては県側 との合意を優先した。

4 月になると市長は佐竹義生宛に、以下のような内容の「舊城 地ノ儀二付上申」を作成した。1 889 年中に拝借を懇願した趣意は、 一市の団体をもって深く旧恩を感戴し、旧君臣の情義を永遠に維 持する精神である。城址の管理を解除しても、「縣公園」や「縣試 作地」を除いて、従来通り引き続き拝借したいとあった ${ }^{59)}$ 。

5 月 6 日の市会で归城地に関する議論があった。まず大縄家令 から市長に宛てて、4月 14 日付で速やかに同地を引き渡寸手続き が求められたこと、4月 30 日付で高等小学校や鐘楼等の用地の扯 借はそのままとし、市民への貸し付け分の返地や引き継ぎ等は家 扶と協議するよう求められたことが報告された。

続けて、城址の管理を解除するにあたって、秋田市が使用中の 高等小学校敷地、同附属用地及び鐘楼敷地は、引き続き抂借の許 可を佐竹家に上申寸ることが審議された。ここでも「旧城の管理」 は長く旧君臣の情誼を維持することが目的であり、解除すること で旧君臣の情義が薄くなり、佐竹家の待遇が自然に冷淡になって くることを䀣念して抵抗する意見が相次いだ ${ }^{60)}$ 。

そして 6 月 20 日市会であらためて秋田市長と佐竹家との約定 書が審議され、秋田市が使用する敷地の貸借などの条件が整理さ れた ${ }^{61)}$ 。6 月 25 日の市参事会で大縄家令から承諾を得たことが 報告され、旧城地の管理解除を佐竹家に上申寸ることを決めた ${ }^{62)}$ 。

\section{（6）佐竹家と秋田県との約定書の締結}

5 月 11 日付で、佐竹家と秋田県で城址の公園化に伴う貸借の約 定書が締結された。その概要は以下の通りである。「嚄秋田城地」 の旧本丸のうち社地と県公園地を除いた土地と旧二の丸や濠水面 などを「公園附属地」として、公園開設中は秋田県が借用する。 借地料は 7 千円として、1897 年度と 1898 年度に各 3,500 円を秋 田県が佐竹家に支払う。借用地はすべて旧形保存の目的で公園の 設計をする。また石木及び石垣、石壇等は現在のまま保存する。 もし設計上、その変更が必要な時は佐竹家の承諾を受ける。借用 地において公園造営上必要な施設は秋田県知事の対応に任すこと などが記されている ${ }^{63)}$ 


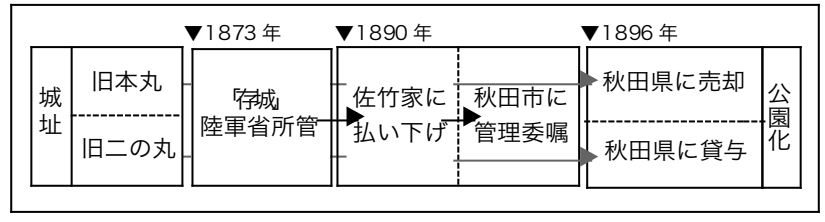

図-1 秋田 (久保田) 城址の所有 - 管理の変遷模式図

そして 5 月 19 日付で、佐竹義生は御代弦を代理人と定め、「萑 城地ノ内秋田縣公園用地卜シテ賣渡及貸渡二係ル土地、秋田縣へ 引渡之事」の権限を委任している ${ }^{64)}$ 。既に御代は秋田市長になっ ていたが、佐竹家の信頼は厚く、秋田県との交涉の空口になった。 特に 4 月から御代は仙台の歩兵第十七連隊と第十六旅団司令部の 誘致活動を積極的に行い、5 月に秋田市への移駐が決まった。そ の敷地についても佐竹家と鋭意交涉していた。

同じ 5 月 19 日付で、佐竹義生から秋田県知事に売り渡し証が 作成された。「旧城地本丸」のうち「秋田縣公園用地」の土地が附 属する木石などとともに 6 千円だった ${ }^{65)}$ 。そして 6 月 18 日付で 佐竹義生は、県公園用地の買い受け代金 6 千円をそのまま招魂社 の再建費に寄付寸る通知を出している ${ }^{66)}$ 。佐竹家では旧本丸の公 園化に伴う売却は自らの利益のためではなく、招魂社等の立地を 伴う公園化を主体的に受け入れていた。

\section{5. まとめ}

本稿では秋田城址の公園化に至る背景や経緯を明らかにした。

1873 年に「存城」として陸軍省の所管となった秋田城址は適切 な管理がされず、一部は畑地や養魚場として賃貸されていた。そ れに対し秋田県と秋田市はそれぞれが主体的に利用する意向を有 していた。1890年に城址は陸軍省にとって不要な土地として、旧 藩主佐竹家に払い下げられた。佐竹家は城址利用の意向を受けて いた秋田市に管理を委嘱した。秋田市は旧本丸での公園開設を計 画し、不要な木石の売却費や土地や濠の賃料をもとに城址に植樹 などを施した。

一方、日清戦争の終結を受け、秋田では焼失していた招魂社の 再建が焦眉の問題だった。有志者が協議し、招魂社を城址に移転 し、秋田県が城址を公園として整備することを計画した。秋田県 は地元有力者とともに城址の譲渡について佐竹家と交涉し、旧本 丸の払い受けと旧二の丸の借用で合意した。県会は「県公園」の 開設を建議し、1896 年度からの三力年継続の公園費を予算化した。 そして秋田県は旧藩主家所有地の管理をしている秋田市を市制上 の問題があると指摘し、管理の解除を指示した。秋田市長や秋田 市参事会員の中には抵抗する意見もあったが、秋田市が設置した 学校と鐘楼用地を継続して借用することで受け入れた。

以上から秋田城址の所有・管理等の変遷を示すと図- 1 の通り である。秋田市は委嘱された管理の範囲内で公園化を企てたが、 その整備は進まなかった。一方、秋田県は招魂社の移転を契機と して旧本丸の買収を伴う公園化に成功した。公園化は招魂社の移 転が目的だった。こうして招魂祭の場が確保されることになり、 さっそく 1896 年 6 月に臨時招魂祭が城址で挙行された。

\section{補注及び引用文献}

1）平井誠(2014）: 明治前期における今治城の払下地について：愛媛県歷史文化博物館 研究紀要 19、11-36

2）野中勝利(2007): 1873年の「廃城」と城址の公園化に関する研究 : 都市計画論文集 $42-3,432-438$

3）平井誠(2011）：明治期における城郭の公園化- 松山公園と道後公園一：愛媛県歴史 文化博物館研究紀要 16、101-138

4) JACAR (アジア歴史資料センター) Ref.C06080856200、1889年『武大日記 8 月』(防 衛省防衛研究所)

5) 小林等(2006) : 松平家文書から見る若松城払下げの事実- 遠藤敬止顕彰碑の検証 : 会津若松市史研究 $8 、 18-62$

6) 野村美紀(2004) : 松平頼壽と別氐陂雲閣一その建設と利用をめぐってー：香川史学
$31 、 45-59$

7) 佐々木孝文(2010) : 近代の鳥取城(2)明治後期から昭和 19 年の鳥取市への寄贈まで : 鳥取城調查研究年報 $3 、 33-42$

8）現在、「秋田城跡」として国指定史跡（1939 年）になっているのは古代出羽国府に 比定される城柵官衙遺跡である。藩政期に佐竹氏の居城があった城址は、千秋公園 (久保田城跡) として市指定名勝（2008 年）になっている。1871 年に久保田藩が 秋田藩に改称され、本稿の対象期間における行政資料、議会資料の中では久保田城 址という表現は確認できない。秋田市及び秋田県の行政資料等では単に「旧城地」 という名称が多用されている。一方、1890年に陸軍省が城址の払い下げを指示した 公文書では「秋田城四千五百円」とあり、1896 年に佐竹家と秋田県の間で締結され た城址の公園化に伴う貸借の約定書では「舊秋田城地」と記されている。そこで本 稿では「久保田城址」ではなく、「秋田城址」を使用する。

9) 長谷川智之(2007) : 秋田・千秋公園にみる長岡安平の設計思想 : 都市公園 179 : 東 京都公園協会、99-103

10) 秋田市史編さん委員会近・現代部会編(2001) : 御代弦日誌 : 秋田市

11) JACAR(アジア歷史資料センター) Ref.C09121381600、明治7年5月 諸県 927 (防 衛省防衛研究所)、JACAR(アジア歴史資料センター)Ref.C09121381800、明治 7 年5月諸県 927 (防衛省防衛研究所)

12）『太政類典』第 5 編・明治 14 年・第 30 巻、国立公文書館蔵

13）『明治十三年 県租税課地理掛事務簿 全・陸軍省往復の部』秋田県公文書館蔵

14）『明治十八年自三月至九月 兵事課庶務掛事務簿』秋田県公文書館蔵

15）『明治十九年自九月至十二月 兵事課事務簿』秋田県公文書館蔵

16) JACAR (アジア歴史資料センター) Ref.C09060318300、明治 11 年規則條例(防衛 省防衛研究所）

17) JACAR (アジア歴史資料センター) Ref.C09070939100、明治 15 年第 5 号審按 従 4 月至 6 月 (防衛省防衛研究所)

18）『兵事課庶務掛事務簿』秋田県公文書館蔵

19）ローラ・D・ガルスト、小貫山信夫訳(2003) : チャールズ・E・ガルスト : 聖学院大 学出版会、91

20) JACAR(アジア歴史資料センター) Ref.C09070980700、明治 15 年第 5 号審按 従 7 月至 9 月 (防衛省防衛研究所)

21）『明治十八年二月四月 兵事課度務掛事務簿』秋田県公文書館蔵

22）『明治二十三年自一月至五月 第一部庶務課事務簿』秋田県公文書館蔵

23）秋田市街の郊外に八橋公園があった。

24）『明治二十三年自一月至五月 第一部庶務課事務簿』秋田県公文書館蔵

25）『明治二十九年 旧城地管理事務簿』秋田市文書法制課蔵

26) JACAR(アジア歴史資料センター) Ref.C07050212200、明治 23 年「伍大日記 2 月」 (防衛省防衛研究所)

27）『明治二十三年五月ヨリ九月マテ 第一部庶務課事務簿』秋田県公文書館蔵

28）『自明治二十四年至明治三十年 旧城借地証書緅』秋田市文書法制課蔵

29）『明治二十三年 秋田市参事会議事録』秋田市文書法制課蔵

30）『自明治二十四年至明治三十年 旧城借地証書緅』秋田市文書法制課蔵

31）『自明治二十四年至明治三十年 旧城借地証書棳』秋田市文書法制課蔵

32）『明治二十三年 秋田市参事会議事録』秋田市文書法制課蔵

33）『明治二十三年 秋田市会会議録』秋田市文書法制課蔵

34) 秋田魁新報、大正 5 年 5 月 1 日

35）『明治二十三年五月ヨリ九月マテ 第一部庶務課事務簿』秋田県公文書館蔵

36) 秋田魁新報、大正 5 年 5 月 1 日

37）『明治二十八年 秋田市会議事録』秋田市文書法制課蔵

38) 前掲: 御代弦日誌: 秋田市、34

39) 前掲: 御代弦日誌: 秋田市、 48

40)『明治二十八年 旧城地管理事務簿』秋田市文書法制課蔵

41）『明治二十八年 市議会事務簿』秋田市文書法制課蔵

42）『明治二十八年 旧城地管理事務簿』秋田市文書法制課蔵

43）『自明治二十六年至明治二十八年 秋田市会決議報告』秋田市文書法制課蔵

44）『明治二十八年 秋田市会議事録』秋田市文書法制課蔵

45）『自明治二十六年至明治二十八年 秋田市会会議録』秋田市文書法制課蔵

46）『明治二十八年 秋田市会議事録』秋田市文書法制課蔵

47) 前掲: 御代弦日誌: 秋田市、49

48) 前掲: 御代弦日誌 : 秋田市、50

49）『明治二十八年 秋田縣通常縣會議事日誌』秋田県公文書館蔵

50）『明治二十八年 秋田縣通常縣會議事録』秋田県公文書館蔵

51）『二十七年度決算共 二十九年度議案』秋田県公文書館蔵

52）『明治二十八年 秋田縣通常縣會議事日誌』秋田県公文書館蔵

53）『明治二十九年 旧城地管理事務簿』秋田市文書法制課蔵

54) 渡部䂝一郎(1989) : 秋田市長列伝 : 秋田魁新報社、63-68

55）『二七年度決算共二十九年度議案』秋田県公文書館蔵

56）『明治二十八年 秋田市参事会議事録』秋田市文書法制課蔵

57）『自明治二十九年至明治三十年 秋田市会決議報告』秋田市文書法制課蔵

58）『明治二十九年 旧城地管理事務簿』秋田市文書法制課蔵

59）『明治二十九年 旧城地管理事務簿』秋田市文書法制課蔵

60）『明治二十九年 秋田市会議事録』秋田市文書法制課蔵

61）『自明治二十九年至明治三十年 秋田市会決議報告』秋田市文書法制課蔵

62）『明治二十八年 秋田市参事会議事録』秋田市文書法制課蔵

63）（1952）: 都道府県立公園及び景勝地 : 厚生省国立公園部、55-56

64）『明治二十九年 旧城地管理事務簿』秋田市文書法制課蔵

65）『明治三十一年自三月至七月 第五課地理係事務簿』秋田県公文書館蔵

66）『明治二十九年 旧城地管理事務簿』秋田市文書法制課蔵 